TAO, Vol.3, No.4, 503-518, December 1992

\title{
Study of the Polarity Transition Record of the Upper Olduvai Event from Wulochi Sedimentary Sequence of the Coastal Range, Eastern Taiwan
}

\author{
TEH-QUEI LEE*
}

(Received: April 21, 1992; Revised: October 22, 1992)

\begin{abstract}
This study presents the preliminary results of the upper Olduvai transition record analyzed from the Wulochi sedimentary sequence of the Coastal Range, eastern Taiwan. Variations of both the declination and paleolatitudes of VGP reveal an antisymmetric characteristic about the mid-point of the transition. However, variation of the VGP latitudes-shows that the first half record is a three stage 'stop and go' pattern similar to that of the same event reported from Po river, Italy, by Tric et al. (1990) while the second half fluctuated more. The later part might also indicate that secular variation of the earth's magnetic field was still dominant during this transition. For the longitudes of the VGP path, they are found to be largely confined to a belt from meridian $200^{\circ}$ to $250^{\circ}$ centered around $230^{\circ}$ which is about $40^{\circ}$ west of the American continents. This result is dissimilar to many other paths which passed through them. However, the Coastal Range has undergone a clockwise rotation of about $30^{\circ}$ during Plio-Pleistocene (Lee, 1989; Lee et al, 1990; 1991); the discrepancy might result from this clockwise rotation event. After the correction of the rotation angle, it is found that the VGP path is much closer to the American continents. In addition, VGP path seems to show a far-field phenomenon and magnetite is identified to be the major magnetic mineral contained in our samples.
\end{abstract}

\section{INTRODUCTION}

Polarity reversal of the geomagnetic field is one of the most remarkable phenomena of our planet. Since Brunhes (1906) first reported that the earth's magnetic field might have changed its polarity in the past, more than 250 polarity intervals have been identified. Now, the geomagnetic polarity time scale is rather well known over a large period of time. However, the detailed transitional process and its characteristics, especially the spatial-temporal dependency, are still not quite understood. In order to find the factors which controlled the

* Institute of Earth Sciences, Academia Sinica, Taipei, Taiwan, R.O.C. 
reversal occurrence of the geomagnetic field, i.e. insight into the mechanism of the geomagnetic dynamo, more detailed records with better resolution about the secular variation and the geometry of the transitional field are needed.

Paleomagnetic records of the polarity transition contribute valuable information about the behavior of the geomagnetic field during a reversal and therefore may be capable of placing constraints on possible reversal mechanisms. In recent years, transitional records have become more available and allow the development of transitional field models (Hillhouse and Cox, 1976; Hoffman, 1977; Hoffman and Fuller, 1978; Fuller et al., 1979; Williams and Fuller, 1981; Hoffman, 1982). Hillhouse and Cox (1976) demonstrated a standing nondipole character of the transitional field from the transitional VGP (virtural geomagnetic pole) path layed in a restricted sector of longitude. Later, models with axisymmetric fields were proposed by Hoffman (1977) and Hoffman and Fuller (1978), which predicted a dependence mainly upon the site latitude for transitional records. Then, evidence for a non-axisymmetric component also led to the 'flooding' model proposed by Hoffman $(1979,1981)$ and Williams and Fuller (1981).

Increasing number of detailed records of the geomagnetic reversal has been published during the last two decades. They have provided important information about some of the principal behaviors of the transitional field. However, these available records are poorly distributed in both the spatial and temporal domains. Most of them are concerned about the transitional geometry of the Matuyama-Brunhes reversal but their site localities are distributed mostly in the mid-latitude of the northern hemisphere (Clement, 1989; Clement \& Kent, 1986; Hillhouse \& Cox, 1976; Niitsuma, 1971; Opdyke et al., 1983; Valet et al., 1988a, 1988b). Only some detailed records about earlier reversals, such as the upper and lower.boundaries of Jaramillo and Olduvai events, Gauss-Matuyama boundary etc., have been reported (HerreroBervera \& Theyer, 1986; Liddicoat, 1982; Tric et al., 1991). In addition, there is a lack of data of several reversals from the same site locality. So, it is not yet possible to make definite statements regarding possible differences from one reversal to another. In addition, because of the complexity of the transitional process, more additional data are required. So, to provide a high-resolution transitional record about the termination of the Olduvai normal event is the purpose of this study.

\section{GEOLOGICAL SETTING}

The Coastal Range of Taiwan is located in an active collision boundary where the Philippine Sea plate has collided with the Eurasian plate since late Miocene. The collision has caused an extremely high uplifting of the Central Range (the highest crest is about 4000 $\mathrm{m}$ high). Since late Pliocene, high erosion and sedimentation rates (about $4-5 \mathrm{~mm} / \mathrm{yr}$ ) have resulted in very thick sedimentary sequences deposited in the Coastal Range (Chi, et al., 1980; Lee, 1989; Lee and Chi, 1990). The sequence contains abundant nannofossils which favor studies of biostratigraphy and magnetostratigraphy. Previous studies have indicated that these thick sedimentary sequences have very high potential to support high resolution transition records regarding the geomagnetic polarity reversals.

The basement of the Coastal Range is the Miocene volcanic Tuluanshan Formation which is composed of tuffs, tuffaceous sandstone, agglomerates and volcanic conglomerates (Hsu, 1956). On the top of this formation, we can often find thin volcaniclastic limestone lentils which are named as the Kangkou Limestone. The Tuluanshan Formation is conformably overlain by a thick sedimentary rock sequence named Takangkou Formation (Hsu, 1956). Lithologically, this sedimentary formation consists of different turbidite facies which are generally composed of thin alternating shale and sandstone beds. However, the conglomerate facies are predominant in the northern part of Coastal Range. 
Wulochi sedimentary sequence located at the middle part of the Coastal Range is mainly composed of thin altemation of shale and sandstone beds of the Takangkou Formation (Figure 1). Relative fine-grained conglomerate beds can also be found in the sequence. The previous paleomagnetic study has assigned this sequence to the age interval from Olduvai normal event up to the middle Matuyama epoch (Lee, 1989; Lee et al., 1988; Lee and Chi, 1990). Samples of this studied transition record are collected from approximately the lowest part of the sequence.
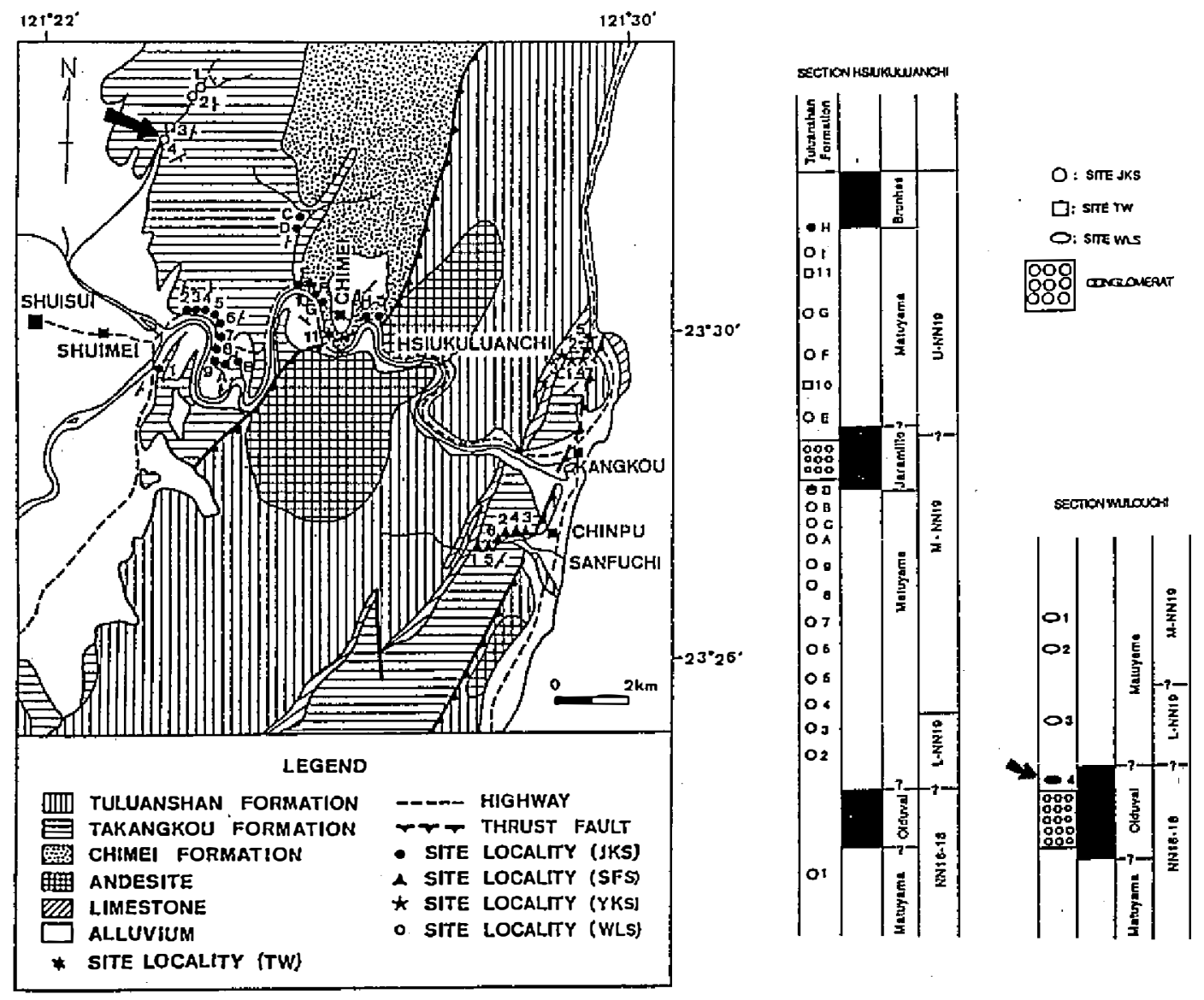

Fig. 1. Sketch map of the Wulochi section, Hsiukuluanchi section and the magnetic time zonations of these two sections (after Lee, 1989). The record of this study was sampled at site WLS04 (indicated by arrow) and its adjacent area.

\section{SAMPLING AND LABORATORY ANALYSIS}

To describe more detailed transition phenomena, records of the intermediate directions within polarity transition zone are generally necessary. In low sedimentation rate rock sequences like deep sea cores, stratigraphically overlapping the sampling distance is usually 
employed in studying the behavior of the geomagnetic field during polarity reversal. The sedimentation rate of the studied area in the Coastal Range has been proved to be very high (4-5 mm/yr) since late Pliocene (Chi et al., 1980; Lee, 1989); in this study the sample interval of two adjacent cores is, therefore, about $10 \mathrm{~cm}$ from which we get the same, or even higher, resolution transition records as the others carried out from low sedimentation sequences. A total of about 100 cores were used for this preliminary study covering an interval in the upper most part 'of the Olduvai normal subchronozone in the Wulochi section (Figure 1).

Samples were collected by electric powered sample corer. Standard paleomagnetic orientation techniques were used to orient the cores. Relative positions of cores were very carefully measured in the field. Each sample was cut into several cylindrical specimens, each one has $22 \mathrm{~mm}$ long and $25 \mathrm{~mm}$ in diameter. Stratigraphical height of each specimen's center was calculated by using their relative locations in the field, their core orientations, bedding directions and also the thickness of the discard parts of each core during cutting. Before analyzing the direction of remanent magnetization, some samples were first chosen for studying the magnetic mineralogy.

Demagnetizing the rock samples, progressive stepwise thermal treatments from room temperature to $550^{\circ} \mathrm{C}$ were employed. Some typical orthogonal component plots are shown in Figure 2 which prove that such processes worked well. Bulk susceptibilities of each specimens were measured after each demagnetization step for the purpose of determining whether the magnetic mineral changes or not during the thermal treatments. Stable components of natural remanent magnetization (NRM) of specimens were determined by applying the linear regression method on directions of several final demagnetization steps shown on the

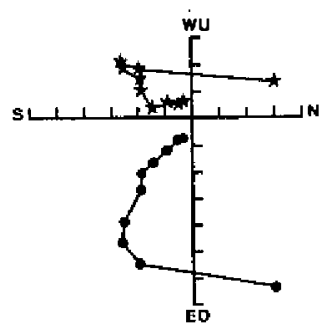

1 Div. $=5 \times 10^{-7} \mathrm{emu} / \mathrm{cc}$ WLOSO1D

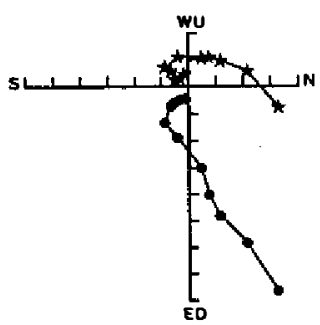

1 Div. $=6 \times 10^{-7} \mathrm{emu} / \mathrm{cc}$ WLOS36B

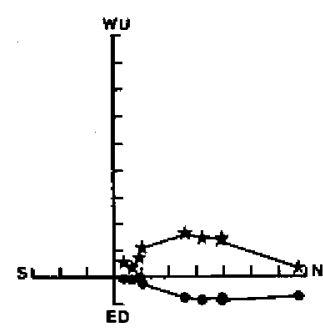

1 Div. $=3 \times 10^{-7} \mathrm{emu} / \mathrm{cc}$ WLOS12B

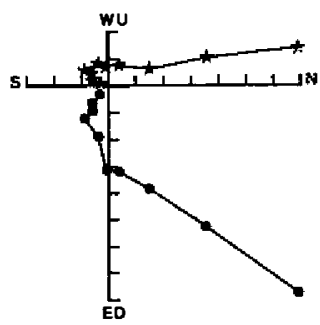

1 Div. $=6 \times 10^{-7} \mathrm{emu} / \mathrm{cc}$ WLOS 25A

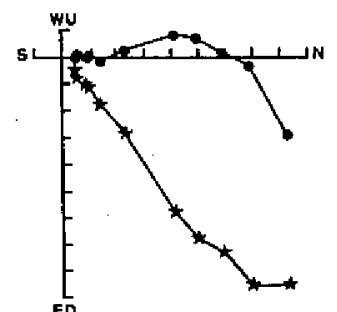

$1 \mathrm{Div} .=8 \times 10^{-7} \mathrm{emu} / \mathrm{cc}$ WLOS47B

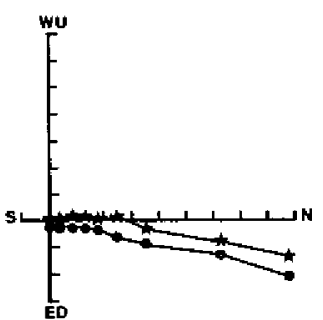

1 Div. $=6 \times 10^{-7} \mathrm{emu} / \mathrm{cc}$ WLOS72C

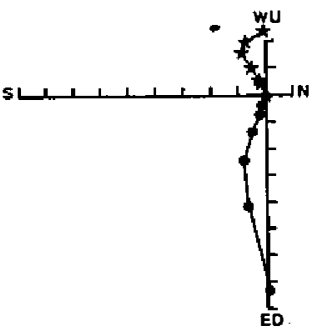

1 Div. $=4 \times 10^{-8} \mathrm{emu} / \mathrm{cc}$ WLOS59B

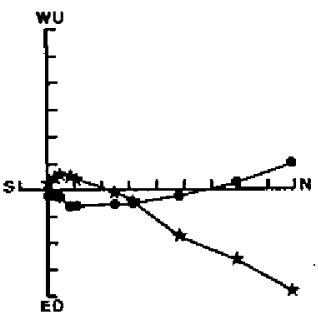

1 Div. $=7 \times 10^{-7} \mathrm{emu} / \mathrm{cc}$ WLOS86B

Fig. 2. Typical Zijderveld (Zijderveld, 1967) plots showing the variation of NRM during thermal demagnetization treatment.(triangle: verticle projection; circle: horizontal projection). 
Zijderveld plot (Zijderveld, 1967). The way we chose the steps will be discussed later. Then, declinations, inclinations and latitudes of virtual geomagnetic poles (VGP) as a function of stratigraphical height were analyzed to investigate the time variation of polarity changes during the transition. Finally, the VGP path on the geographical coordinates is studied for analysis of the geometry of the transition record.

\section{MAGNETIC MINERALOGY}

Identifying magnetic minerals contained in the analyzed rock samples is very important for paleomagnetic studies to get a reliable direction of the remanent magnetizations. Several different methods have been applied for such purpose (Dunlop, 1972; Lowrie and Heller, 1982; Ozdemir and Banerjee, 1982; Kissel et al., 1985; 1986; Lee et al., 1986; 1988; 1990). In this study, the acquisition curves of isothermal remanent magnetization (RM) and the median destructive field (MDF) of the saturation IRM are employed to investigate the principal magnetic minerals in our samples.

Figure 3 presents the typical IRM acquisition curves of samples from the studied Wulochi section. Obviously, samples acquired the saturation IRM at the applied field less than $300 \mathrm{mT}$. This phenomenon confirms that the major magnetic mineral contained in our rock samples should not be hematite or goethite, because they obtain their saturation IRM generally at an applied field stronger than $2.5 \mathrm{~T}$ and $1.5 \mathrm{~T}$ (Lowrie and Heller, 1982), respectively. So, magnetite will probably dominate in our samples. Figure 4 shows the typical altemating field demagnetization curves of the saturation IRM of samples. It could be found that almost all of the samples have their MDFs less than $50 \mathrm{mT}$. These results also indicate that magnetite probably is the major magnetic carrier of our samples which is in close agreement with the previous suggestion.

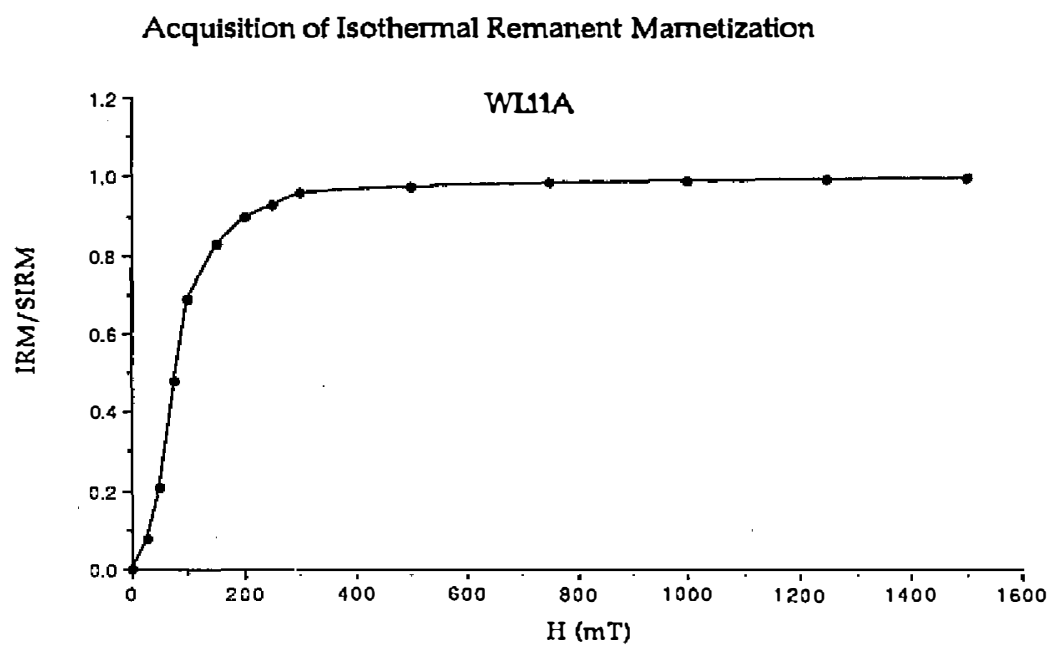

Fig. 3. Typical normalized acquisition curve of IRM from Wulochi sequence showing that sample acquired the saturation IRM at the applied field less than $300 \mathrm{mT}$. 
AF Demagnetization of SIRM

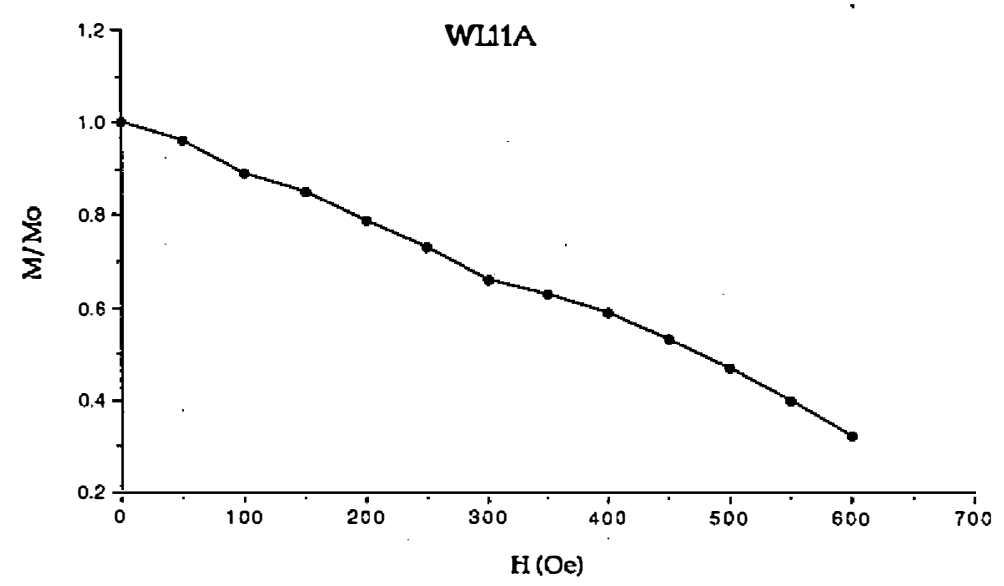

Fig. 4. Typical normalized AF demagnetization curve of SIRM from Wulochi sequence showing that the MDF of sample is less than $40 \mathrm{mT}$.

\section{RESULTS}

The bulk susceptibilities of samples as a function of temperature show that they did not change or only slightly decreased before the demagnetization steps up to $450^{\circ} \mathrm{C}$ but increased obviously after $500^{\circ} \mathrm{C}$ (Figure 5). This indicates that magnetic minerals might not have changed or only a small amount changed between room temperature and $450^{\circ} \mathrm{C}$. Besides, the typical demagnetization curves of samples (Figure 2) indicate that after a few low temperature thermal treatment steps, the secondary components of NRM could be cleaned. Both of these results suggest that the characteristic directions of NRM of the studied samples could be determined by applying the linear regression method on several demagnetized steps before $450^{\circ} \mathrm{C}$. The results are presented in Table 1 and show that about 80 intermediate paleomagnetic directions were obtained. In addition, the stratigraphical height, intensity of NRM before demagnetization and the correspondent calculated VGP position of each specimen are also shown on this table.

The distributions of paleo-declinations, inclinations and paleolatitudes of samples as a function of stratigraphical height of the studied transition record are shown in Figure 6, and Figure 7 shows the correspondent VGP path plotted on the geographical coordinates. From Figure 6, we find that the pattems seem to propose an antisymmetric characteristics about the mid-point, near the stratigraphical height $1900 \mathrm{~cm}$, of the transition record from the declination (relative to $90^{\circ}$ ) and paleolatitude (relative to equator) data; however, the paleoinclination seems to show a symmetric phenomenon about the same stratigraphic height. In addition, it is easy to find from Figure 7 that the longitudes of the VGP path are largely confined into a range of meridians from $200^{\circ} \mathrm{E}$ to $250^{\circ} \mathrm{E}$ centering around $230^{\circ} \mathrm{E}$ which is about $110^{\circ}$ east of the sampling site (located at longitude of $121.3^{\circ} \mathrm{E}$ ) located inside the Pacific Ocean. 

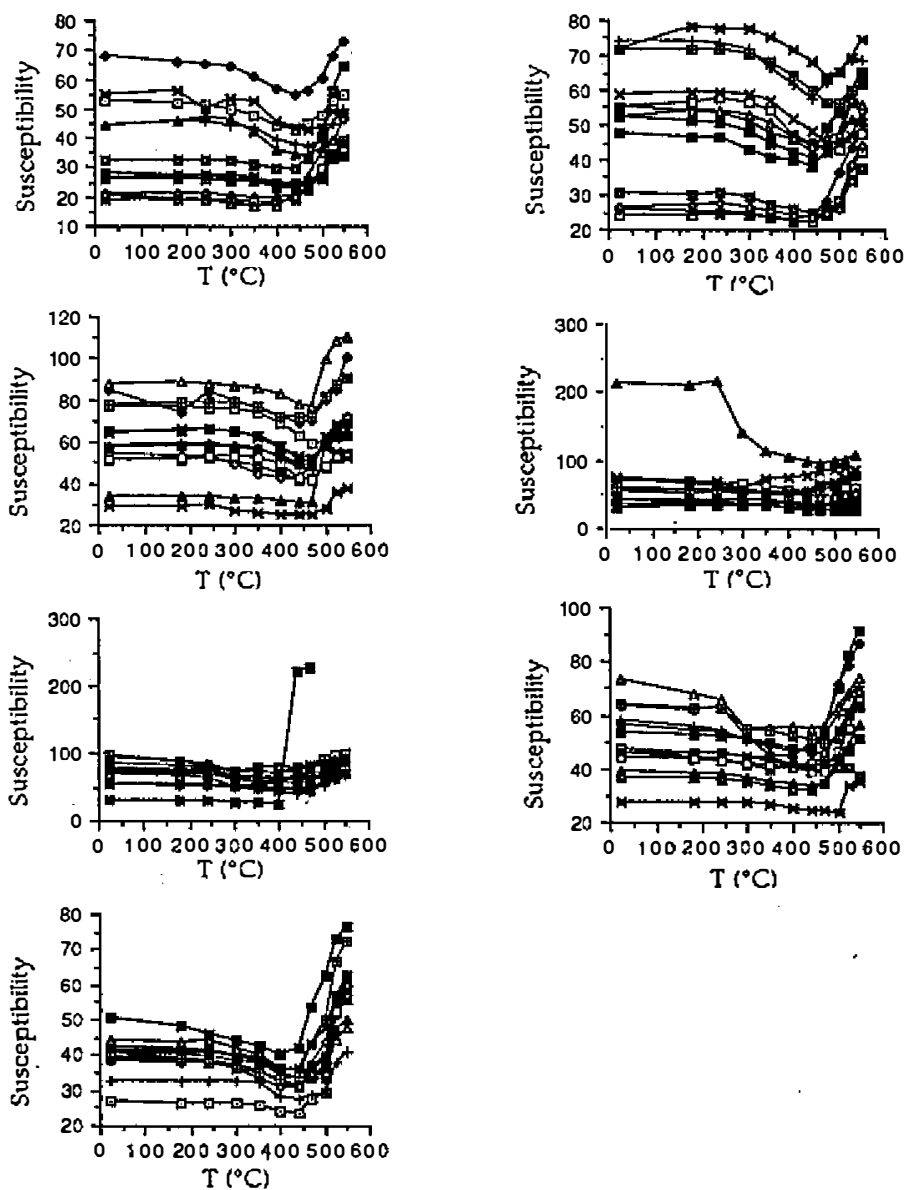

Fig. 5. Distribution of bulk susceptibility of samples during thermal demagnetization treatment.

\section{DISCUSSION}

From Figure 6, it is easy to find that the record indicates lack of stable normal and reversed directions at the commencement and termination of the studied transition event respectively. This is, unfortunately, due to the difficulty of collecting the samples outside both ends of this record in the field. However, despite the relativity large numbers of intermediate directions, very few records provided about 80 intermediate paleomagnetic directions as this study, enabling us to study more in detail about the behavior of the geomagnetic field during its polarity reversal. For example, the variation patterns of declinations and paleolatitudes show antisymmetric characteristics about the mid-point (Figure 6) as firstly reported. The paleolatitude variation of VGP indicates that the variation of transition path might be reversible in time domain, at least for the paleo-latitudes, for either from normal end to reversed or from reversed end to normal. In addition, the patterns shown in Figure 6 seem to indicate that secular variation of the geomagnetic field was probably still dominated during the transition of this event. This reveals that the dipole component of the earth's magnetic field probably did not completely vanish during the transition. 
Table 1. Paleomagnetic results of the samples collected from the upper Olduvai transition in the Wulochi sedimentary sequence.

\begin{tabular}{lrrrrl} 
SAMPLE & DEC. & INC. & \multicolumn{1}{r}{ PLAT } & PLON & F(NRM) \\
\hline WLOS1.0 & 119.4 & -20.1 & -31.0 & 209.6 & $3.9841 \mathrm{E}-5$ \\
WLOS2.0 & 156.6 & -11.7 & -61.4 & 177.1 & $7.1935 \mathrm{E}-5$ \\
WLOS3.0 & 105.2 & -24.7 & -18.9 & 217.7 & $2.3502 \mathrm{E}-5$ \\
WLOS4.0 & 87.2 & -43.2 & -7.4 & 235.7 & $1.5367 \mathrm{E}-5$ \\
WLOS5.0 & 4.0 & -11.3 & 60.5 & 293.3 & $1.7075 \mathrm{E}-5$ \\
WLOS6.0 & 12.9 & -7.6 & 59.9 & 275.0 & $6.9745 \mathrm{E}-6$ \\
WLOS7.0 & 355.5 & 6.4 & 69.2 & 192.8 & $8.3835 \mathrm{E}-5$ \\
WLOS8.0 & 130.4 & 16.1 & -32.1 & 184.2 & $1.4291 \mathrm{E}-5$ \\
WLOS9.0 & 116.3 & -9.2 & -25.9 & 204.9 & $1.3111 \mathrm{E}-5$ \\
WLOS10.0 & 58.4 & 33.3 & 35.5 & 205.2 & $5.3542 \mathrm{E}-5$ \\
WLOS11.0 & 356.0 & -8.3 & 62.1 & 188.5 & $3.3416 \mathrm{E}-5$ \\
WLOS12.0 & 12.5 & -23.2 & 52.4 & 281.1 & $2.2660 \mathrm{E}-5$ \\
WLOS13.0 & 18.7 & 16.2 & 66.5 & 248.7 & $6.6081 \mathrm{E}-5$ \\
WLOS14.0 & 86.1 & 24.1 & 8.5 & 201.3 & $1.2948 \mathrm{E}-5$ \\
WLOS16.0 & 122.2 & -29.2 & -35.3 & 214.4 & $1.4965 \mathrm{E}-5$ \\
WLOS17.0 & 9.7 & 20.3 & 74.0 & 264.4 & $2.1818 \mathrm{E}-5$ \\
WLOS18.0 & 116.7 & -17.0 & -27.9 & 208.9 & $1.9957 \mathrm{E}-5$ \\
WLOS19.0 & 28.6 & -19.1 & 46.5 & 258.2 & $7.3264 \mathrm{E}-5$ \\
WLOS20.0 & 25.8 & 5.9 & 57.7 & 247.0 & $6.4861 \mathrm{E}-5$ \\
WLOS21.0 & 342.2 & -70.9 & 9.7 & 190.2 & $3.0790 \mathrm{E}-5$ \\
WLOS22.0 & 102.7 & -28.1 & -17.3 & 220.6 & $5.1492 \mathrm{E}-5$ \\
WLOS23.0 & 113.6 & -56.1 & -32.2 & 241.1 & $7.3397 \mathrm{E}-5$ \\
WLOS24.0 & 117.4 & -40.2 & -33.0 & 224.3 & $9.0858 \mathrm{E}-5$ \\
WLOS25.0 & 106.1 & -27.5 & -20.3 & 219.0 & $5.6057 \mathrm{E}-5$ \\
WLOS26.0 & 146.2 & -37.9 & -58.7 & 214.0 & $7.0903 \mathrm{E}-5$ \\
WLOS27.0 & 141.0 & -44.4 & -54.6 & 223.9 & $5.3640 \mathrm{E}-5$ \\
WLOS28.0 & 59.3 & 43.7 & 36.5 & 196.1 & $8.8825 \mathrm{E}-5$ \\
WLOS31.0 & 155.6 & 18.6 & -49.2 & 160.0 & $2.7033 \mathrm{E}-5$ \\
WLOS32.0 & 141.8 & 3.6 & -45.1 & 182.4 & $5.4486 \mathrm{E}-5$ \\
WLOS33.0 & 180.3 & -8.5 & -70.8 & 359.1 & $6.5011 \mathrm{E}-5$ \\
WLOS34.0 & 173.2 & 8.2 & -61.6 & 135.8 & $4.3594 \mathrm{E}-5$ \\
WLOS35.0 & 130.5 & 11.2 & -33.6 & 186.7 & $1.1255 \mathrm{E}-4$ \\
WLOS36.0 & 123.2 & -23.4 & -35.1 & 210.0 & $6.9965 \mathrm{E}-5$ \\
WLOS58.0 & & & &
\end{tabular}


Table 1. (Continued)

\begin{tabular}{lrrrrl} 
SAMPLE & DEC. & INC. & PLAT & PLON & F(NRM) \\
\hline WLOS59.0 & 92.3 & -19.9 & -6.2 & 219.9 & $3.4276 \mathrm{E}-4$ \\
WLOS60.0 & 106.8 & -23.8 & -20.2 & 216.6 & $1.6133 \mathrm{E}-4$ \\
WLOS61.0 & 70.9 & -58.7 & -1.2 & 254.5 & $1.7692 \mathrm{E}-4$ \\
WLOS62.0 & 69.0 & -54.2 & 2.5 & 251.2 & $1.0046 \mathrm{E}-4$ \\
WLOS63.0 & 51.2 & -34.9 & 24.3 & 247.6 & $1.0695 \mathrm{E}-4$ \\
WLOS64.0 & 16.3 & -34.3 & 44.8 & 279.4 & $1.9094 \mathrm{E}-4$ \\
WLOS65.0 & 123.6 & -28.0 & -36.4 & 213.0 & $1.0493 \mathrm{E}-4$ \\
WLOS66.0 & 124.2 & -68.6 & -39.2 & 260.2 & $6.0956 \mathrm{E}-5$ \\
WLOS67.0 & 66.6 & -48.9 & 6.8 & 248.1 & $2.0012 \mathrm{E}-4$ \\
WLOS68.0 & 358.6 & -1.5 & 65.7 & 183.4 & $7.5681 \mathrm{E}-5$ \\
WLOS69.0 & 37.5 & -35.3 & 33.6 & 257.9 & $1.2620 \mathrm{E}-4$ \\
WLOS70.0 & 28.7 & -7.2 & 51.0 & 251.7 & $7.4867 \mathrm{E}-5$ \\
WLOS71.0 & 16.5 & 22.5 & 70.4 & 245.5 & $6.1461 \mathrm{E}-5$ \\
WLOS72.0 & 10.6 & -3.0 & 63.0 & 277.5 & $6.0817 \mathrm{E}-5$ \\
WLOS73.0 & 22.3 & -26.7 & 46.5 & 269.1 & $2.1778 \mathrm{E}-4$ \\
WLOS74.0 & 153.9 & -18.1 & -61.3 & 186.1 & $1.4164 \mathrm{E}-5$ \\
WLOS75.0 & 12.5 & -4.8 & 61.4 & 274.6 & $1.2424 \mathrm{E}-4$ \\
WLOS76.0 & 359.1 & 3.5 & 68.2 & 182.4 & $8.7344 \mathrm{E}-5$ \\
WLOS77.0 & 351.9 & 20.0 & 74.7 & 211.7 & $5.3028 \mathrm{E}-5$ \\
WLOS78.0 & 27.6 & -6.5 & 52.1 & 252.6 & $2.3750 \mathrm{E}-5$ \\
WLOS80.0 & 21.6 & -1.1 & 58.1 & 257.3 & $2.0548 \mathrm{E}-5$ \\
WLOS81.0 & 354.0 & 4.8 & 68.1 & 196.3 & $6.3528 \mathrm{E}-5$ \\
WLOS82.0 & 335.2 & -16.4 & 50.0 & 220.2 & $4.9488 \mathrm{E}-5$ \\
\hline DEC $:$ Declination
\end{tabular}

DEC. : Declination

PLAT : Paleo-latitude of VGP

F(NRM) : Intensity of NRM

PLON : Paleo-longitude of VGP
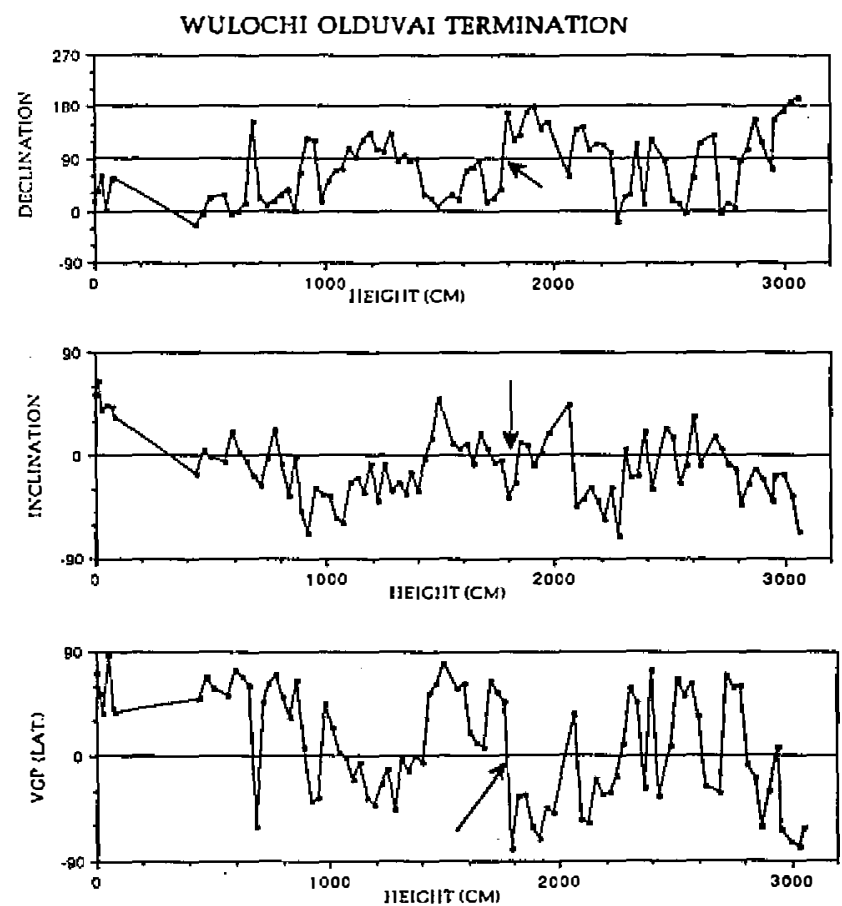

Fig. 6. Distributions of declination, inclination and paleolatitudes as a function of stratigraphical height of the transition record from the termination of the Olduvai subchronozone in Wulochi sequence. The anti-symmetric center is presented by an arrow. 
Comparing the VGP path of this study (Figure 7) to that reported by Herrero-Bervera \& Theyer (1986), the same geomagnetic event but samples collected from North Pacific deep sea sediments (site longitude about $180^{\circ} \mathrm{E}$ ), they look very similar (Figure 8). If we put the site localities of these two records together, i.e. considering the common site effect, we can find that two paths are almost identical except that this study has more intermediate directions during the transition of polarity reversal. This phenomenon proposes a non-axisymmetric behaviour during polarity transition of the geomagnetic field at least for the studied transition record of the upper Olduvai normal to reversed polarity reversal. Also both records show a far-field phenomenon-the VGP paths located at more than $90^{\circ}$ far away from the sampling sites.

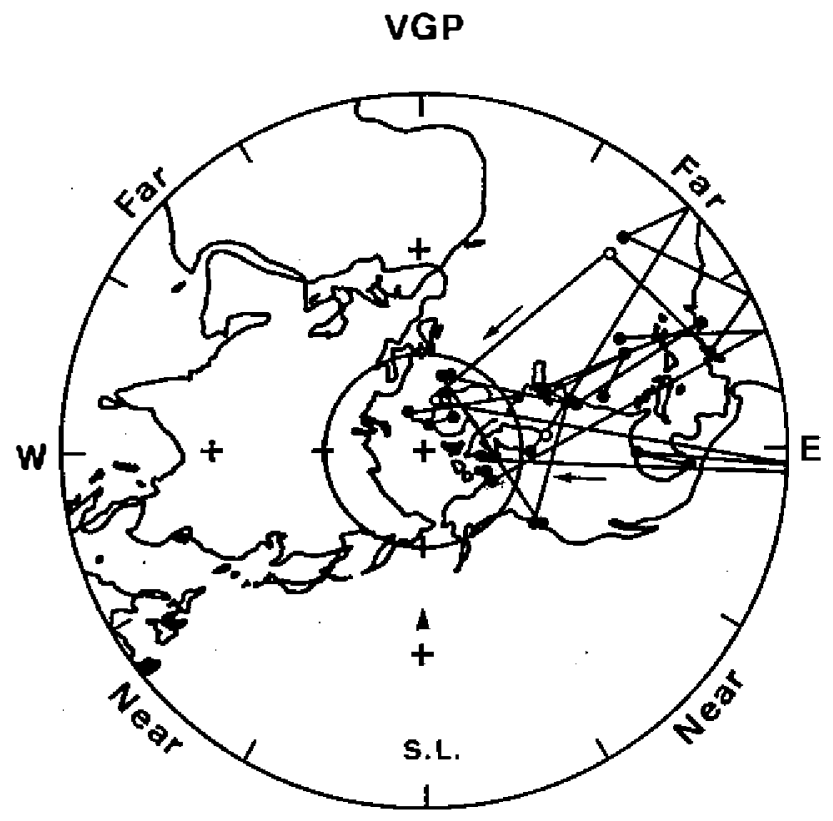

Fig. 7. VGP path of the upper Olduvai transition from the Wulochi section plotted on the geographical coordinates. (open circle: VGP located at southern hemisphere; closed circle: VGP located at northern hemisphere).

Meanwhile, most of the VGP positions are located unusually at least $40^{\circ}$ away from the western coast of the American continents, passing through the so-called quiet zone, the center of the Pacific Ocean. This phenomenon is clearly different from most of the published transition records compiled by Laj et al. (1991), passing through the meridians of the American continents and their western nearby offshore area or their antipodal regions. However, previous paleomagnetic studies (Lee, 1989; Lee et al., 1990; 1991) have pointed out that the Coastal Range has undergone a clockwise rotation of about $30^{\circ}$ during PlioPleistocene; the VGP positions, therefore, have to be corrected. After doing such correction of rotation angle, it was found that the VGP path is much closer to the American continents and approches the others but still has $20^{\circ}$ to $30^{\circ}$ offset between them. Such disagreement might suggest that the non-dipolar effect dominated during transition of polarity reversal. However, there was only one transition record reported in eastern Asia before; whether there exists a non-dipolar effect during polarity transition of the termination of the Olduvai event 


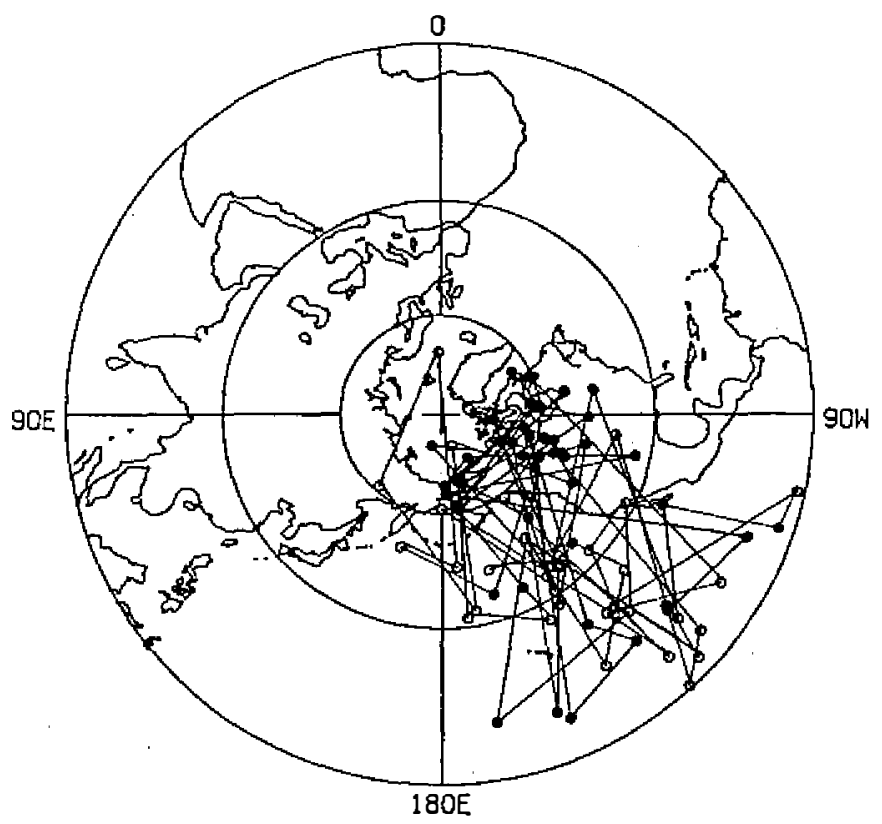

Fig. 8. VGP path of the upper Olduvai transition from the Pacific marine cores (after Herrero-Bervera \& Theyer, 1986).

or it is only the local effect in the Coastal Range is desirous of further study.

Analyzing the latitude variation of the VGP path of the same upper Olduvai transition record from Po Valley, Italy, Tric et al. (1991) revealed a three stages 'stop and go' pattem during polarity reversal (Figure 9a). They described that the VGP path first moved to the low latitudes around the equator when the transition began and stayed there for a while (phases 1-2), then returned to the original high latitudes (phase 2), and lasted a long time (phases 2-4); finally the VGPs changed latitudes towards the opposite hemisphere (phase 4) and finished the transition. They also pointed out that there might have been sedimentary intemuption occurring at the Po Valley area at the end of the transition which caused the record to be incomplete. Comparing the latitude variation of the VGP path of the present record from Wulochi section to Po Valley result (Figure 9), it can be found that the pattern of the first half of our transition record (Figure 9b) is quite similar to that of Po valley between phase 1 and phase 4; however, our second half record indicates more fluctuation. The distance between these two sampling sites is very great. The similarity between both records seems to propose that the dipole component of the geomagnetic field might still dominate, at least for this event, as the non-dipole component during polarity reversal. In addition, the fluctuation of our second half record might also suggest that the secular variation of the earth's magnetic field probably still existed during the transition.

\section{SUMMARY}

From this study, several important features about the changes of the earth's magnetic field during polarity transition at the termination of the Olduvai normal subchronozone have been investigated: 

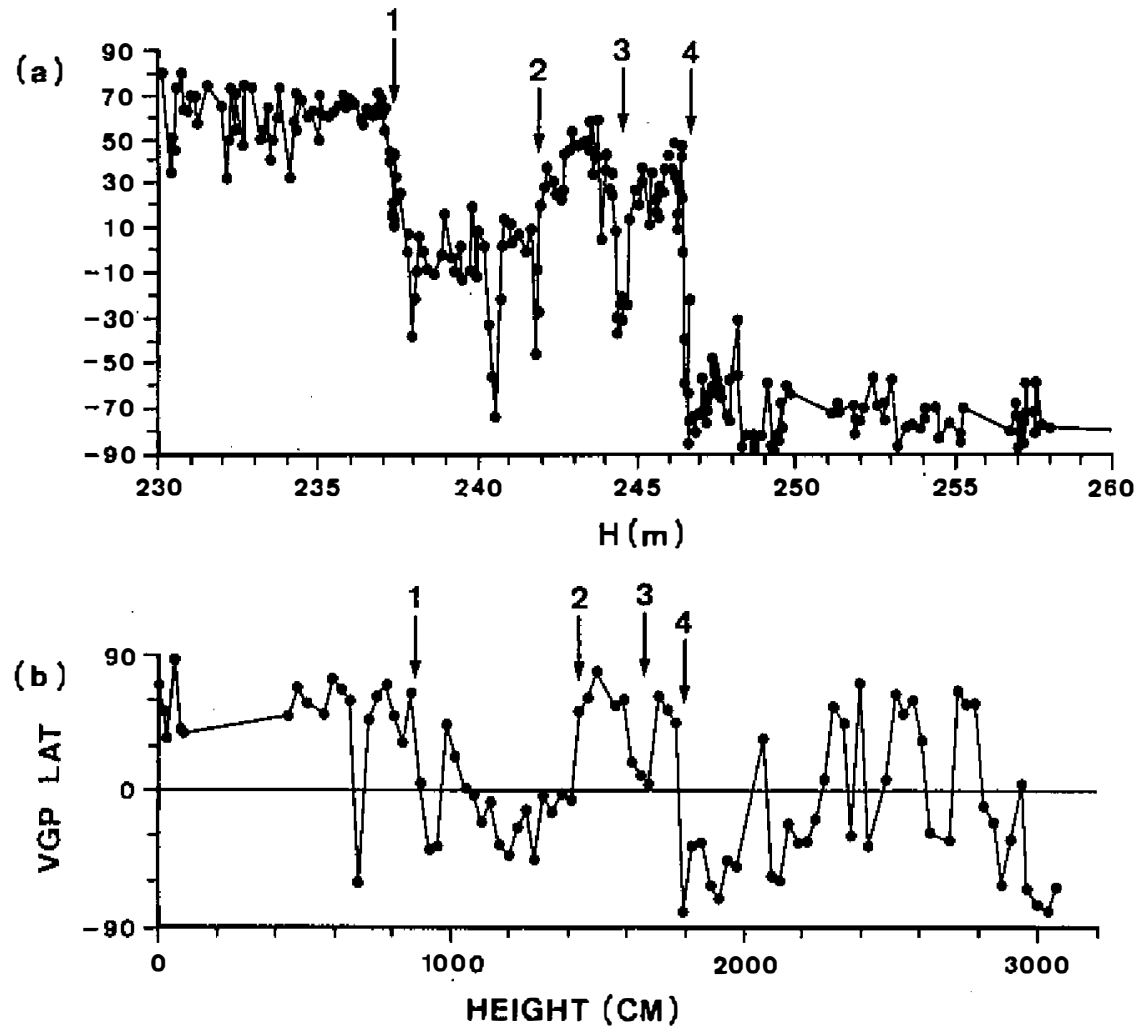

Fig. 9. Comparison of the latitude variation of VGP path of the upper Olduvai transition between the results from (a) Po river (Tric et al., 1991) and (b) this study. The arrows numbered 1, 2, 3, 4 indicate the correspondent positions between these two records which show a 'stop and go' pattern.

(1). The major magnetic mineral of the samples is identified as most probably being magnetite.

(2). The longitude of VGP path is largely confined to a range from $200^{\circ}$ to $250^{\circ}$ centering around $230^{\circ}$ which is about $110^{\circ}$ east of the sampling site at longitude of $121.3^{\circ} \mathrm{E}$. It is similar to that around $300^{\circ}$ of the same event for the site from North Pacific deep sea sediments (longitude about $180^{\circ}$ ) reported by Herrero-Bervera \& Theyer (1986). It shows a far-field phenomenon.

(3). Geographically, the VGP path of this study is unlike most of the transition records showing their path passed through the meridians on the American continents and its nearby offshore area. This might propose that a non-dipolar effect dominated during this polarity reversal.

(4). The VGP latitude variation shows at least three-stages "stop and go" pattern during transition. It is quite similar to that of Tric et al. (1991) which proposes that the dipole field component of the earth magnetic field might not completely vanish during the transition of the upper Olduvai normal-to-reversed polarity reversal. 
(5). During the transition, the paleo-secular variation was still observed.

(6). An antisymmetric characteristic about the mid-point (Figure 6) of the transition record is first found from the variation patterns of declinations and paleolatitudes. This indicates that the variation of transition path might be reversible in time domain, at least for the paleo-latitudes, for either from normal end to reversed or from reversed end to normal

Acknowledgements This study is partially supported by National Science Council of R.O.C. under granted NSC78-0202-M001-21. Contribution of Institute of Earth Sciences, Academia Sinica No. IESEP92-023.

\section{REFERENCES}

Brunhes, B., 1906: Recherches sur la direction d'aimantation des roches volcaniques, $J$. Phys., 5, 705-724.

Chi, W. R., J. Namson and W. W. Mei, 1980: Calcareous nannoplankton biostratigraphy of the Neogene sediments exposed along the Hsiukuluanchi in the Coastal Range, eastern Taiwan, Petrol. Geol. Taiwan, 17, 75-87.

Clement, B. M., 1989: Longitudinal distribution of Brunhes-Matuyama transition VGPs, Abstract GP51A-13, EOS, 70, 1073.

Clement, B. M. and D. V. Kent, 1986: Geomagnetic polarity transition records from five hydraulic piston core sites in the north Atlantic, In: W. F. Ruddiman, R. Kidd, E. Thomas (editors), Init. Reps. DSDP. U.S. Govt. Printing office, Washington DC., 94, 831-852.

Dunlop, D. J., 1972: Magnetic mineralogy of unheated and heated red sediments by coercivity specrum analysis, Geophys. J. R. Astro: Soc., 27, 37-55.

Fuller, M., I. Williams and K. A. Hoffman, 1979: Paleomagnetic records of geomagnetic field reversals and the morphology of the transitional field, Rev. Geophys. Space Phys., 17, 179-203.

Herrero-Bervera E. and F. Theyer, 1986: Non-axisymmetric behaviour of Olduvai and Jaramillo polarity transitions in north-central Pacific deep-sea sediments, Nature, 322, 159-162.

Hillhouse, J. and A. Cox, 1976: Brunhes-Matuyama polarity transition, Earth Planet. Sci. Lett., 29, 51-64.

Hoffman, K. A., 1977: Polarity transition records and the geomagnetic dynamo, Science, 196, 1329-1332.

Hoffman, K. A., 1979: Behavior of the geodynamo during reversal: a phenomenological model, Earth Planet. Sci. Lett., 44, 7-17.

Hoffman, K. A., 1981: Quantitative description of the geomagnetic field during the MatuyamaBrunhes polarity transition, Phys. Earth Planet. Inter., 24, 229-235.

Hoffman, K. A., 1982: The testing of geomagnetic reversal models: Recent developments, Phil. Trans. R. Soc. London, A306, 147-159.

Hoffman, K. and M. Fuller, 1978: Transitional field configuration and geomagnetic reversals, Nature, 273, 715-718. 
Hsu, T. L., 1956: Geology of the Coastal Range, eastern Taiwan, Bull. Geol. Surv. Taiwan, 8, 39-63.

Kissel, C., Laj, C. and C. Muller, 1985: Tertiary geodynamical evolution of Northwestern Greece: paleomagnetic results, Earth Planet. Sci. Lett., 72, 190-204.

Kissel, C., Barrier, E., Laj, C. and T. Q. Lee, 1986: Magnetic fabric in "undeformed" marine clays from compressional zones, Tectonics, 5, 769-781.

Laj, C., R. Weeks and M. Fuller, 1989: Observations and models of reversal transition fields, in F. J. Lowes et al. (eds.) "Geomagnetism and Paleomagnetism", 185- 203.

Laj, C., A. Mazaud, R. Weeks and M. Fuller, 1991: Geomagnetic reversal paths, Nature, $351,447$.

Lee, T. Q., 1989: Evolution tctonique et godynamique nogne et quaternaire de la chane ctire de Taiwan: apport du palomagntisme, Thse de doctoral de l'univ. Pierre et Marie Curie (Paris 6), France, 328pp. (in French).

Lee, T. Q., Kissel, C., Homg, C. S., Lue, Y. T. and C. Laj, 1986: Paleomagnetic study of the sedimentary rocks along the Hsiukuluan river, eastern Taiwan, Bull. Inst. Earth Sci., Academia Sinica, 6, 169-184.

Lee, T. Q., Chi, W. R., Kissel, C. and E. Barrier, 1988: Magnetic polarity zonation of two sedimentary rock sequences in the middle and southern parts of eastern Coastal range, Taiwan, ACTA Geologica Taiwanica, 26, 179-192.

Lee, T. Q. and W. R. Chi, 1990: Paleomagnetic time interval of the sedimentary sequences in Coastal Range, Proc. Central Geol. Survey, 4, 271-294 (in Chinese).

Lee, T. Q., Kissel, C., Laj, C., Horng, C. S. and Y. T. Lue, 1990: Magnetic fabric analysis of the Plio-Pleistocene sedimentary formations of the Coastal Range of Taiwan, Earth Planet. Sci. Lett., 98, 1, 23-32.

Lee, T. Q., C. Kissel, E. Barrier, C. Laj and W. R. Chi, 1991: Paleomagnetic evidence for a diachronic clockwise rotation of the Coastal Range, eastern Taiwan, Earth Planet. Sci. Lett., 104, 245-257.

Liddicoat, J. C., 1982: Gauss-Matuyama polarity transition, Phil. Trans. R. Soc. Lond., A306, 121-128.

Lowrie W. and F. Heller, 1982: Magnetic properties of Marine limestone, Rev. Geophys Space Phys., 20, 171-192.

Niitsuma, N. D., 1971: Paleomagnetic and paleoenvironmental study of sediments recording Matuyama-Brunhes geomagnetic reversal, Tohoku Univ. Sci. Rep. Geol., 43, 1-39.

Opdyke, N. D., D. V. Kent and W. Lowrie, 1983: Details of magnetic polarity transitions recorded in high deposition rate, deep-sea core, Earth Planet. Sci. Lett., 20, 315324.

Ozdemir, O., and S. K. Banerjee, 1982: A preliminary magnetic study of soil samples from west-central Minnesota, Earth Planet. Sci. Lett., 59, 393-403.

Tric, E., C. Laj, C. Jehanno, J.-P. Valet, C. Kissel, A. Mazaud and S. Jaccarina, 1991: High-resolution record of the upper Olduvai transition from Po Valley (Italy) sediments: support for dipolar transition geometry?, Phys. Earth Planet. Int., 65, 319-336.

Valet, J. P., L. Tauxe and D. R. Clark, 1988a: The Matuyama-Brunhes transition recorded from the lake Tecopa sediments (California), Earth Planet. Sci. Lett., 87, 463-472. 
Valet, J. P., L. Tauxe and J. Bloemendhal, 1988b: The Matuyama-Brunhes geomagnetic reversal from two deep-sea cores of the east-equatorial Atlantic, Proc. ODP, 108.

Williams, I. and M. Fuller, 1981: A Miocene polarity transition (R-N) from the Agno batholith, Luzon. J. Geophys. Res., 87, 9408-9418.

Zijderveld, J. D. A., 1967: AF demagnetization of rocks: Analysis of results, in "Methods in Paleomagnetism" edited by Collinson, D. W., R. M. Creer and S. K. Runcom, 254-286, Elsevier, New York. 


\title{
台灣束部海岸山脈鳥漏溪沉積岩剖面古地磁場 奥都威事件頂部極性反轉過程之研究
}

\author{
李 德 貴 \\ 中央研究院地球科學研究所
}

摘要

本文將介紹分析採自台管束部海岸山脈鳥漏溪沉積岩剖面岩 樣所記錄古地磁場奥都威事件頂部極性反轉過程之初步研究結果 , 從磁偏角與古磁䋨度之戀化發現一個具有相對於轉置過程中心 點之反向對稱特性; 而視磁極位置隨緯度變化曲線則顯示磁場轉 置期間前半段路徑, 虚一走走停停之現象, 此結果與Tric 等人 ( 1991 ) 分析採自義大利波河平原同一極性反轉事件有相似的結果 ; 至於後半段的變化路徑改變相當快速，可能指出反轉期間地磁 場的長時期變化仍然顯著, 又視磁極路徑之經度變化, 集中於自 格林威治子午面向束起算 $200^{\circ}$ 到 $250^{\circ}$ 間的帶狀區域内, 大約在距 美洲大陸西岸經度 $40^{\circ}$ 以西之地方, 這一路徑與許多已弡表的記 錄它們係經過美洲大陸不同, 然而早期古地磁結果顯示, 海岸 山脈地區在上新一更新世時期有大約 $30^{\circ}$ 之順時針旋轉現象 (Lee ，1989; Lee et al., 1990; 1991), 由於本研究地區可能受到它的 影響, 因此作旋轉角度之修正後, 發現視磁極路徑之經度變化 有較接近美洲大陸之䞨势, 而與其它記䥻漸䞨一致。若考虑共 同點址特性, 似乎視磁極位置曲線影示遠場現象。此外, 磁鐵 礦被爁定爲本次所採岩樣的主要带磁性礦物。 